NBER WORKING PAPER SERIES

THE EFFECT OF TAXES ON EFFICIENCY AND GROWTH

\author{
Martin Feldstein \\ Working Paper 12201 \\ http://www.nber.org/papers/w12201 \\ NATIONAL BUREAU OF ECONOMIC RESEARCH \\ 1050 Massachusetts Avenue \\ Cambridge, MA 02138
}

May 2006

Professor of Economics, Harvard University, and President and CEO of the National Bureau of Economic Research. This paper is based on remarks to the National Association for Business Economics in Washington, D.C. on March 14, 2006. The views expressed herein are those of the author(s) and do not necessarily reflect the views of the National Bureau of Economic Research.

(C)2006 by Martin Feldstein. All rights reserved. Short sections of text, not to exceed two paragraphs, may be quoted without explicit permission provided that full credit, including (C) notice, is given to the source. 
The Effect of Taxes on Efficiency and Growth

Martin Feldstein

NBER Working Paper No. 12201

May 2006

JEL No. H2

\begin{abstract}
$\underline{\text { ABSTRACT }}$
This nontechnical paper discusses the adverse effects of high marginal tax rates on labor income and on investment income. It explains that the deadweight loss of a tax on labor income depends on the response of taxable income and not just the change in labor supply. An across the board increase in personal tax rates involves a deadweight loss of 76 cents per dollar of revenue and only collects about two-thirds of the revenue implied by a "static" calculation.

A tax on investment income brings a deadweight loss even if household saving does not respond to taxes and the net rate of return. What matters is the response of future consumption. The tax on investment income is also effectively a tax on labor supply because current work effort produces income that will be spent on future consumption and the tax on investment income reduces the future consumption that results from more work today.

An appendix shows for a simple log utility case that the tax on labor income has a smaller deadweight loss than a tax on investment income with the same present value of revenue.

There is a further discussion of the various ways in which capital income taxes distort economic activity.

Martin S. Feldstein

National Bureau of Economic Research

1050 Massachusetts Avenue

Cambridge, MA 02138-5398

msfeldst@nber.org
\end{abstract}




\section{The Effect of Taxes on Efficiency and Growth}

\section{Martin Feldstein}

The taxes collected by the federal, state and local governments now take one third of GDP. Marginal tax rates are even higher. And it is the marginal tax rates that determine the efficiency costs - i.e., the deadweight losses - of the tax system.

A typical wage earner now pays a combined marginal tax rate of about 45 percent on incremental pay - a 25 percent federal personal income tax rate, a 15.3 percent combined employer-employee payroll tax, and a state income tax of about 5 percent. State and local sales taxes often put the total over 50 percent. And that is for someone who earns as little as $\$ 40,000$ a year.

Understanding the magnitude and nature of the deadweight losses - i.e., of the efficiency losses - is important for assessing the true cost of increased government spending and for shaping the appropriate structure of taxes.

The good news is that marginal tax rates are lower today than they were in the past and that the deadweight losses of the tax system are therefore correspondingly lower. Back in 1963, the highest marginal tax rate in the personal income tax was 93 percent. A

\footnotetext{
*Professor of Economics, Harvard University, and President and CEO of the National Bureau of Economic Research. This paper is based on remarks to the National Association for Business Economics in Washington, D.C. on March 14, 2006 
taxpayer in the top bracket got to keep only 7 cents out of every extra dollar that he earned. (I used to work for one of those taxpayers: Ronald Reagan. And his memory of the adverse effects of such high tax rates is an important reason that we have much lower marginal tax rates today.)

Even as recently as 1980 , the top income tax rate was 70 percent on interest and dividends and 50 percent on wages and other personal services income. Today the top federal marginal income tax rate is 35 percent, although the effective marginal tax rate rises to about 40 percent when the Medicare payroll tax and the phase-out of deductions are taken into account. In some high-income two earner families, one of the earners is still subject to the marginal payroll tax, raising this 40 percent marginal tax rate to more than 50 percent.

The tax rates on capital income have come down even more than the rates on personal services income. The corporate tax rate is down from 46 percent in 1980 to 35 percent now. The maximum tax rate on capital gains, which in 1980 could reach more than 40 percent as a result of tax add-ons and offsets, is now down to 15 percent, although that could revert to 25 percent if Congress does not renew the current rates. Similarly, the current 15 percent rate on dividend income will revert to the full marginal tax rate of 35-plus percent if Congress does not act.

It would be wrong to conclude from these reduced rates on dividends and capital gains that the tax on investment income is now low. The full tax on capital income includes not only the taxes paid by the individual investors but also the corporate income tax. When 
these taxes are combined, the result is still a tax that can do a great deal of economic harm.

\section{Taxes on Labor Income}

Taxes on labor income have much larger effects than are generally recognized, even by economists who study taxation. Traditionally, studies of the effects of payroll taxes and the personal income tax focus on the effect of the marginal tax rate on working hours. A higher marginal tax rate reduces the net return to work and therefore depresses working hours. This reduction in working hours creates a deadweight loss equal to the difference between the value of the lost net output and the value to the individual of the extra leisure. This approach implies that the deadweight loss is proportional to the compensated elasticity of the hours worked with respect to the net of tax wage or, equivalently, the elasticity with respect to the net of tax share that the individual gets to keep, i.e., to one-minus-the-marginaltax-rate.

With this focus on working hours, economists have therefore estimated the elasticity of hours worked with respect to the net of tax wage. For men and for single women, the evidence indicates that elasticity is very low, implying a low deadweight loss of the tax on labor income. Only for married women is there a substantial elasticity. For them the elasticity of hours worked with respect to the net of tax share is about one, implying a significant deadweight loss relative to the revenue raised by any increase in the marginal tax rate.

Since married women are only a fraction of the total labor force, 
this research has been interpreted to mean that the overall deadweight loss of taxes on labor income is relatively small.

This conclusion is badly wrong. An important aspect of the mistake lies in the measure of labor supply. The number of hours worked is a terrible measure of labor supply. The contribution of employees to national output depends not just on the number of hours worked but also on the amount of human capital per worker (including education, on-the-job-training, and experience), on the effort that workers make, on the choice of occupation, on location, on risk-taking and on other attributes of labor supply.

Each of these aspects of labor supply contributes to output and each of them is affected by taxation. As higher marginal tax rates reduce each aspect of labor supply, they cause a deadweight loss equal to the difference between the value of the lost net output and the value ("disutility") to the individual of providing that form of labor input. If I make a greater effort as I work - whether physical or mental or emotional - I forego some leisure - not in minutes of leisure but in units of effort. Because the tax falls on the cash wage but not on that form of leisure, I choose to provide less effort. And the difference between the value of the resulting loss of output and the value to me of that foregone leisure is the deadweight loss. A similar analysis would indicate the deadweight loss caused when higher marginal tax rates induce individuals to accumulate less human capital, to take more pleasant but less productive jobs, to choose locations where it is more pleasant to live but where wages are lower, etc..

In each case, the individual faces a reward for providing more 
labor input - broadly defined - but that reward is reduced by the marginal tax rate.

The loss of labor input is only part of the deadweight loss caused by higher marginal tax rates. Taxes also distort the form in which individuals take their compensation. We receive compensation not only in cash but also in a variety of other forms that might be described as fringe benefits and working conditions. Fringe benefits include such things as health insurance, subsidized meals at work, access to health club facilities, etc.. The working conditions include not only the quality of the workplace itself but, for those who travel on business, the class of travel and accommodation and meals that they can enjoy.

Of course, even in the absence of taxes there would be fringe benefits and nice working conditions. But the fact that cash compensation is taxed and the other forms of compensation are not taxed tips the balance to increase compensation in the nonaged form. More specifically, each nonaged form of compensation is increased until the value of a dollar spent on it by the employer is worth oneminus-the-marginal-tax-rate to the employee. If my marginal tax rate is 35 percent, I will want to expand my consumption of each form of nontaxable compensation until at the margin it is worth only 65 cents to me, the same net amount that I would get from a dollar of taxable cash. At that point, a dollar of taxable cash compensation and a dollar of untaxed compensation both produce the same net value.

This behavior induces a deadweight loss equal to the difference between the cost of producing the fringe benefit or other form of 
compensation and the value to the individual. At the final margin, this value per dollar of fringe benefit equals one minus the individual's marginal tax rate.

It may seem at first that we have a very difficult problem of adding up all of the deadweight losses that result from changes in the different forms of labor supply and in the different forms of compensation. Fortunately, that's not true. The deadweight loss can be measured by the effect of the tax on the employee's taxable labor income. It doesn't matter if the taxable income is reduced because the employee works fewer hours or makes less effort per hour or chooses an untaxed form of compensation. In each case, the wedge between the value of the output or nonaged benefit and the value to the individual is given by one-minus-the-marginal-tax-rate. Economic theory tells us that in this case we can simply add all of the distortions, i.e., add all of the reductions in taxable income, to get the full distorting effect of the tax. ${ }^{1}$

This implies a much larger deadweight loss than the very small loss of taxable income that results from reductions in working hours.

In addition to reducing labor supply broadly defined and changing the form of compensation to benefits that are worth less to the individual than they cost to produce, the personal income tax creates a third type of deadweight loss by inducing individuals to spend more on deductible forms of consumption. Housing expenditures in the form of mortgage interest and local property taxes

\footnotetext{
${ }^{1}$ See Martin Feldstein, "Tax Avoidance and the Deadweight Loss of the Income Tax," Review of Economics and Statistics, Novermber 1999.
} 
are the largest but not the only form of such induced increase in consumption.

The increases in each form of tax-preferred consumption induces a deadweight loss equal to the difference between the cost of production and the value to the individual, a value that is reduced by the fact that the consumption can be bought at a cost equal to the net of tax rate. Since I buy incremental housing and other tax-preferred consumption at the same price (i.e., at one minus my marginal tax rate) as I buy fringe benefits and leisure, all of these distortions contribute equally to the overall deadweight loss to the extent that they reduce taxable labor income.

An important implication of all of this is that the deadweight loss caused by changes in personal income tax rates depends on the elasticity of the taxable labor income with respect to one-minus-themarginal tax rate. This elasticity is obviously a much, much bigger number that the elasticity of working hours with respect to the same net of tax share. It therefore implies a much bigger deadweight loss than economists have thought about when they focused on the response of hours.

A second important implication is that this overall deadweight loss can be estimated empirically because we can estimate the elasticity of taxable income with respect to the net of tax share.

A number of economists have been working on estimating this important elasticity. I used data on individual tax returns to study the 
effect of the tax rate reductions in the tax reform act of $1986 .{ }^{2} \mathrm{~A}$ special feature of these data, which were provided by the Treasury as a public use sample, is that they followed a random sample of individuals for several years. It is possible therefore to compare the taxable income of individuals several years before the 1986 tax act with their taxable incomes several years after the 1986 tax reform act. The analysis implied that the elasticity of taxable income with respect to one-minus-the-marginal-tax rate is about one. (As a technical matter, this is an estimate of the compensated elasticity and therefore of the value needed for calculating the deadweight loss.)

Although an elasticity of one is much larger than the traditional elasticities associated with working hours, it is not surprisingly large when one recognizes that it includes every aspect of change in behavior - changes in labor supply broadly defined, changes in the form of compensation, and changes in the consumption of tax preferred forms of spending. An elasticity of one implies that reducing someone's marginal tax rate from 40 percent to 30 percent i.e., increasing the marginal net of tax share from 60 percent to 70 percent - implies about a 16 percent increase in taxable income.

Other economists have worked with different data sets and obtained different estimates. Some of these estimates have been higher and others have been lower. Because those studies did not use panel data that followed the same individuals through time, I think that their estimates are less persuasive. I also suspect that my own estimates may understate the relevant long run elasticity because I

${ }^{2}$ Martin Feldstein, “The Effect of Marginal Tax Rates on Taxable Income: A Panel Study of the 1986 Tax Reform Act," Journal of Policitical Economy, 1997 
was only able to observe changes in taxable income over an interval of about 6 years. This is long enough for there to be changes in hours and effort and in some forms of compensation, but not long enough for significant changes in human capital and occupation. Because of its importance, this is likely to continue to be an active area of research, one that will be greatly assisted if the Treasury Department will release more recent panel data.

Armed with an estimated elasticity, it is possible to calculate the effect of a change in marginal tax rates on deadweight loss as well as on tax revenue. I am grateful to my National Bureau of Economic Research colleague Dan Feenberg for the following estimates based on a large Treasury public use sample of individual tax returns for 2001 which he made using the NBER Taxsim calculator. The analysis raised all marginal tax rates by on percent, i.e., it converted the 15 percent rate to a 15.15 percent rate, the 25 percent rate to 25.25 percent, etc. For simplicity, the change was not made to capital gains (which behave very differently) and no adjustment was for the alternative minimum tax or to various credit provisions.

With no behavioral response, this across the board increase in tax rates raised the total tax liability by $\$ 7.5$ billion. In Washington jargon, this is the "static" estimate of the additional revenue. To study the effect of a very modest response to tax changes, the analysis assumed a compensated elasticity of only 0.4 (rather than the 1.0 that I estimated using the 1986 tax reform experience.) We also assumed an income effect of 0.15 , implying that the overall (uncompensated) elasticity of taxable income with respect to the net of tax share is less than 0.4. More specifically, the income effect implies that each 
dollar's reduction in income that would result from the rise in tax rates if there were no behavioral response causes taxable income to rise by 15 cents; thus the $\$ 7.5$ billion static increase in revenue would cause individuals to change their behavior in ways that would raise taxable income by $\$ 1.1$ billion. The rationale for this income effect is that the rise in the tax rates leaves taxpayers with less disposable income, causing them to want to work more, to receive more of their potential income in cash rather than in some other form, and to cut back their spending on tax favored forms of consumption.

With these assumptions, the 1 percent rise in all marginal rates causes taxable income to decline by $\$ 6.6$ billion. As a result of this decline in taxable income, the incremental personal income tax revenue of $\$ 7.5$ billion declines by $\$ 2.4$ billion, or 32 percent. The resulting increase in personal income tax revenue is therefore only $\$ 5.0$ billion or 68 percent of the static estimate.

In addition to this decline in personal tax revenue, there is also a fall in the payroll tax revenue equal to $\$ 400$ million. This reduces the incremental total federal revenue to $\$ 4.6$ billion or only 57 percent of the static estimate.

The deadweight loss produced by the rise in marginal tax rates is $\$ 3.5$ billion or 76 percent of the $\$ 4.6$ billion of incremental revenue. ${ }^{3}$

\footnotetext{
${ }^{3}$ The increased deadweight loss for each individual is the difference between the deadweight loss at the individual's final marginal tax rate (t2) and at the initial marginal tax rate $(\mathrm{t} 1)$. We calculate this difference for each individual and then aggregate as a weighted sum using the weights provided by the Treasury data. The marginal tax rates include the personal income tax rate, the payroll tax rate and the state income tax rate. Only the federal tax rate is adjusted. The expression for the incremental deadweight loss is 
This implies that financing additional government spending by an across the board rise in all marginal tax rates would make the cost per dollar of government spending equal to $\$ 1.76$.

These two facts - that the actual revenue is only 57 percent of the static revenue gain and that the deadweight loss is 76 cents per dollar of revenue - should be central to any consideration of tax policy. And yet they are not. Neither the Treasury staff nor the Congressional revenue estimators produce either number to help the politically responsible individuals make decisions. The revenue estimators continue to produce revenue estimates that are explicitly constrained to assume no change in GDP. With that assumption, they intentionally miss the reduction in taxable income that results from changes in labor supply broadly defined.

Moreover, there is no way to separate the changes in taxable income that result from changes in GDP from those that result from changes in the form of compensation or in tax preferred consumption. Any attempt to estimate the revenue effect of changes in the form of compensation separately from other changes in taxable income cannot be more than a guess. And the guesses of the revenue estimators imply very small responses.

The result of this failure to take into account the behavior of taxpayers leads the revenue estimators to overestimate the positive effect on revenue of tax rate increases and also to overestimate the negative effect on revenue of tax rate decreases. This builds in a

$0.5 \mathbf{E}\left[(\mathrm{t} 2)^{2}-(\mathrm{t} 1)^{2}\right] \mathrm{TLI} /(1-\mathrm{t} 1)$ where TLI is the initial taxable labor income.. 
tendency to favor raising tax rates and to oppose lowering tax rates.

The failure to estimate the efficiency effects of alternative tax changes also leaves the policy process without the information that it needs. Certainly any policy official who contemplates an increase in government spending needs to understand that each extra dollar of outlays actually costs the country - including the deadweight losses $\$ 1.76$ if the spending is financed by an across the board increase in all tax rates. If the spending were financed by a relative increase in the higher tax rates, the deadweight loss per dollar of spending would be even higher.

In contrast to the label "static revenue estimate" that is used to refer to those revenue estimates that assume no behavioral response, the revenue estimates that recognize the impact of tax rates on taxpayer behavior have been called "dynamic" estimates even when they do not take into account any long-term effects that would really make them deserve the title of being dynamic. Taxes on labor income can have long-term effects which magnify the distorting effects that we can study with the kind of estimates that I have been describing.

A higher tax on labor income discourages human capital investments and entrepreneurial activities. More research would make it possible to be able to take these into account. But even before this is done, the Treasury and the Congressional revenue estimators can estimate the effects of proposed tax changes on taxable income and can introduce the measurement of deadweight losses into the process of policy analysis. 
It is very encouraging to me that the Administration has recently proposed the creation of a Division of Dynamic Analysis within the Treasury department. I hope that it will focus on the revenue and efficiency effects of simple behavioral responses as well as on the more difficult problems of full-scale dynamic modeling of the role of taxes in the economy.

\section{Taxes on Investment Income}

Let me turn now to taxes on investment income: the corporate income tax and the taxes levied on the dividends, interest, and capital gains received by individuals.

As I indicated earlier in my remarks, the taxation of such income is becoming less distorting, with lower tax rates at both the corporate and personal level. The decline in the rate of inflation has helped to achieve this lower effective tax rate since, when inflation was at double-digit levels, the taxation of nominal capital gains and the use of historic cost depreciation raised the effective tax rate substantially. And yet, even with today's relatively low rate of inflation and the reduced taxes on dividends and capital gains, the combined burden of the tax remains very high.

There are two kinds of efficiency losses that result from the current taxation of different types of capital income. First, any tax or combination of taxes that reduces the net of tax return to savers causes an efficiency loss by distorting the level of retirement consumption that results from any given saving rate. The nature of this distortion and the magnitude of the potential deadweight loss is still very badly 
understood.

Second, there are a variety of specific distortions that come about because of the structure of capital income taxation: the allocation of capital between corporate and noncorporate forms of business, the decision of companies to pay dividends or to retain earnings, the mix of debt and equity finance, the realization of capital gains, and the location of businesses in the US and abroad. The tax structure affects each of these decisions in ways that contribute to deadweight losses.

Consider first the distortion caused by any capital tax that reduces the net return to savers. This includes the corporate tax and the taxes paid by individuals on dividends, interest, capital gains and bequests. Despite the recent reductions in the tax rates on dividends and capital gains, the cumulative effect of the corporate tax and the individual taxes can take more than one third of the real pretax return to capital of an individual saver. Even the saving that takes place in IRAs and 401(k) accounts is subject to a large tax wedge because of the combination of the corporate tax and the ultimate taxation on disbursements at ordinary income tax rates. And for those whose saving exceeds the maximum amount that can be deposited in IRAs and $401(\mathrm{k})$ accounts, the marginal distortion in the return to saving is as large as it would be without those tax preferred accounts.

The reduced rate of return to savers creates a deadweight loss that is larger than is generally understood. Here's why.

It is natural (but incorrect) to think about the deadweight loss 
that is caused by taxing the return to saving by asking how much that tax reduces the volume of saving. That would seem to be analogous to evaluating the deadweight loss of a tax on apples by asking how much that tax reduces the volume of apples consumed. Moreover, many economists still think - incorrectly in my judgement - that savings are not responsive to the net rate of return. Combining this view of a low saving responsiveness with the approach that measures the efficiency loss by looking at how the tax affects the volume of saving leads to the conclusion that taxes on the return to saving create little deadweight loss.

That inference is wrong because the deadweight loss of a tax on the return to saving depends on how the tax affects future consumption, not on how it affects current saving. Why? Because deadweight losses depend on how taxes affect the thing that people care about - that, in the jargon of economics, the thing that is in their utility function. We care about how much we consume both now and in the future, not about how much we save to achieve that future consumption.

The right way to think about saving is that it is the amount that we "spend" today to buy future consumption. When we think about a tax on apples, we measure the deadweight loss by looking at the impact of the tax on the number of apples that are consumed, not on how much individuals spend on buying apples. If a tax that raises the price of apples by 10 percent causes a 10 percent reduction in the number of apples consumed, there will be no change in what the individual spends on buying apples. The same old level of spending simply buys 10 percent fewer apples. We recognize that that causes a 
deadweight loss even though there is no change in the amount spent. Similarly, if a tax on capital income reduces the future consumption that a dollar's worth of saving can buy, we should focus on how much that future consumption is reduced and not on what happens to the amount of saving that is used to buy that future consumption.

This shift of focus from the impact of the tax on the volume of saving to the impact of the tax on future consumption has a very profound effect. Even if the tax does not change saving at all, it has a very large effect on future consumption and therefore can create a large deadweight loss. ${ }^{4}$

An example will help to illustrate that point. Assume that the marginal product of capital is 10 percent. In the absence of all capital taxes, that is the real rate of return that the individual would receive. If the combination of corporate and personal taxes at the federal and state level take half of this return, the net real return to the individual would be 5 percent. Now think about someone who saves at age 45 and dissaves 30 years later at age 75 . With a 10 percent real rate of return, each dollar saved at age 45 grows to $\$ 17.45$. In contrast with a 5 percent rate of return, a dollar saved at age 45 grows to only $\$ 4.32$. So if saving is unchanged, the value of future consumption per dollar of saving falls from $\$ 17.45$ to $\$ 4.32$, a decline of 75 percent.

This example has two implications. First, it can be shown that the individual would be better off if the government collected the same amount of revenue by a lump sum tax or a tax on labor income at age 45

\footnotetext{
${ }^{4}$ The issue here is more than just the difference between a zero uncompensated elasticity of supply of savings and a positive compensated elasticity of supply of savings. 
and allowed the individual to invest the remainder at the higher rate of return. ${ }^{5}$

Second, the example is a reminder that a tax on investment income is effectively also a tax on the reward for extra work since some of the income from that work would be saved and consumed during retirement. An important part of the deadweight loss caused by a tax on investment income is the result of reducing the incentive to work and to receive cash earnings. If each extra dollar of earnings at age 45 buys $\$ 17.45$ of retirement income at age 75 , the individual has much more incentive to earn income than if those extra dollars can only buy $\$ 4.32$ of retirement consumption. So the tax that reduces the return to saving reduces labor supply broadly defined, including not only the number of hours worked but, more importantly, the incentive to acquire human capital, the choice of occupation, and the amount of effort. And since the tax on the return to saving makes cash income less valuable, it also distorts the form in which the individual will choose to be paid, selecting more in the form of fringe benefits and nice working conditions.

This effect occurs even if the tax on the return to saving does not alter the amount of saving. But my reading of the evidence on saving is that taxes that lower the return to saving do reduce saving. The most convincing evidence on this point are the studies of 401(k) plans by David Wise and his coauthors that show that individuals who have access to 401(k) plans save substantially more than those who do not.

This adverse effect of taxes on saving has three important implications. First, it implies that the deadweight loss caused by the

${ }^{5}$ The appendix to this paper provides a formal analysis of this point. 
tax is even larger than it would be if saving remains unchanged.

Second, it implies that the tax revenue from taxing the return to saving is less than a "static" analysis would imply. And third it implies that the existing high taxes on investment income depress the rate of capital accumulation and growth. The slower rate of growth lowers the future standard of living and also reduces future tax revenues.

\section{Distorting the Use of Capital}

I turn now to consider briefly the four ways in which our complex system of taxing capital income distorts the use of capital in the economy.

First, the differential taxation of profits in the corporate sector first by the corporate income tax and then by the taxes on dividends and capital gains - drives capital out of the corporate sector and into other activities, particularly into foreign investment and real estate (both owner occupied and rental property) . Shifting capital abroad causes a real loss of income in the United States with a shift of tax revenue from the U.S. Treasury to foreign governments. The shift of capital from corporate businesses to real estate creates a loss of efficiency because it creates a gap between the higher pretax return to capital in the corporate sector and the lower return to capital in the more lightly taxed real estate sector. The reduction of the corporate tax rate from 46 percent to 35 percent in 1986 reduced this deadweight loss. And by keeping more of the capital in the corporate sector, it caused the revenue loss to be less than the static estimate of the reduction implied. Similarly, the lower tax rates on dividends and capital gains also help to keep capital in the corporate sector and this 
reduces the revenue cost of those lower tax rates. A failure of Congress to extend the current tax rates on capital gains and dividends would exacerbate the sectoral misallocation of capital and would produce less revenue that the static revenue estimates imply.

Second, the recent reduction in the tax rate on dividends led many corporations to start paying dividends and many others to increase their dividend payout rates. If the Congress now makes the current tax rate on dividends "permanent," i.e., if it eliminates the return to the higher tax rate implied by current law, dividends are very likely to be raised further. Such a rise in dividends would improve economic efficiency by making funds available to new and growing businesses. A higher dividend payout rate also disciplines corporate managements by forcing them to seek outside funding. The rise in dividends also means that the government collects more revenue than would be implied by a static analysis of the reduced dividend tax rate.

Third, the current tax system encourages firms to use debt finance rather than equity finance because interest payments are deductible by the borrowing firm in calculating its taxable income. By encouraging the use of debt in this way, the tax system makes firms more vulnerable to adverse business cycle conditions. The increase in debt also causes firms to be more cautious in their investments, foregoing projects with more uncertain payoffs or with longer-term payoffs even if those would be more productive. In both of these ways, the bias toward debt finance is a source of economic inefficiency. One of the advantages of the recent reduction in the tax on dividends is that it reduces this bias in favor of debt. 
Fourth, the capital gains tax distorts the realization of capital gains and the selling of capital assets. The capital gains tax is essentially a voluntary tax since individuals can postpone the realization of the capital gain and the payment of the resulting tax liability. They can even avoid the tax liability completely by using the appreciated property to make a charitable contribution or by holding it until they bequeath it at death. The extent to which the tax is voluntary can be seen by comparing the relatively small amount of taxable capital gain reported each year and the full amount of the accrued gain. Statistical studies based on individual tax return data also show that individuals are deterred from selling stock and realizing gains and that the effect is larger when capital gains taxes are higher.

An individual investor's decision not to sell appreciated property reduces the funds available for new and growing businesses. It also causes the investor to have a riskier portfolio than he would otherwise want because he has retained more of the appreciated stock. More generally, it discourages investors from shifting funds to those companies in which they would choose to invest if they were not locked into old positions by the potential capital gain tax liability. Each of these causes a deadweight loss and also reduces tax revenue. Lowering the capital gains tax rate to a maximum of 15 percent thus reduces efficiency losses and reduces revenue by less than a static forecast would predict.

\section{Concluding Thoughts}

The tax system today is more efficient than it was in the past because tax rates are lower on all forms of income. But marginal tax 
rates are still high and the efficiency costs of the resulting distortions are much greater than is generally understood. High personal income tax rates reduce not only labor supply broadly defined but also distort the form of compensation and encourage spending on tax favored forms of consumption. The large elasticity of taxable income with respect to the net of tax rate is an indication of the magnitude of the deadweight loss as well as of the loss in revenue.

Taxes on capital income also produce very large deadweight losses by reducing future consumption even when the saving rate itself is not very sensitive to the net rate of return. This impact on future consumption implies that a tax on the income that is saved also reduces labor supply broadly defined and distorts the form of compensation. The combination of taxes on corporate profits, dividends and capital gains introduce further efficiency costs and depress tax revenue in a variety of ways.

Much could be done to improve the tax policy process. The revenue estimators could recognize and report the extent to which taxes change behavior in both the short run and the longer term. The measurement of economic efficiency and deadweight losses deserves to be a focus of their analysis alongside estimates of the effects on tax revenue.

My sense is that the need for these changes is now better understood in both the academic world and in Washington. That makes me optimistic about the future path of tax policy.

Cambridge MA 
March 2006

\section{Appendix}

This appendix presents a simple example that illustrates how a labor income tax can produce a lower deadweight loss than a tax on investment income in a two period life cycle model.

The individual has a log-linear utility function

$$
\mathrm{u}=\ln \mathrm{C} 1+\ln \mathrm{C} 2+\ln \mathrm{L}
$$

where $\mathrm{C} 1$ and $\mathrm{C} 2$ are consumption during the two periods of life and $\mathrm{L}$ is the leisure during the first period. The individual is assumed to be fully retired in the second period.

The individual's lifetime budget constraint is

$$
[\mathrm{w}(1-\mathrm{t})(1-\mathrm{L})-\mathrm{C} 1][1+(1-\mathrm{T}) \mathrm{r}]=\mathrm{C} 2
$$

where $t$ is the labor income tax, $\mathrm{T}$ is the tax on investment income and $r$ is the pretax real rate of return on savings.

Substituting this expression for $\mathrm{C} 2$ into the utility function and maximizing utility with respect to $\mathrm{L}$ and $\mathrm{C} 1$ implies first order conditions:

$$
\mathrm{L}=1 / 3
$$




$$
\begin{gathered}
\mathrm{C} 1=\mathrm{w}(1-\mathrm{t}) / 3 \\
\mathrm{C} 2=\mathrm{w}(1-\mathrm{t})[1+(1-\mathrm{T}) \mathrm{r}] / 3 .
\end{gathered}
$$

Substituting these expressions into the utility function and simplifying implies

$$
\mathrm{u}=-3 \ln 3+2 \ln [\mathrm{w}(1-\mathrm{t})]+\ln [1+(1-\mathrm{T}) \mathrm{r}]
$$

The revenue from a labor income tax is

$$
\mathrm{TAXL}=\mathrm{t} \mathrm{w}(1-\mathrm{L})
$$

or

$$
\mathrm{TAXL}=2 \mathrm{t} \mathrm{w} / 3 .
$$

The revenue from a capital income tax, collected in the second period, is

$$
\text { TAXCAP }=\text { T r }[\mathrm{w}(1-\mathrm{t})(1-\mathrm{L})-\mathrm{C} 1]
$$

If there is no labor income tax, this simplifies to

$$
\mathrm{TAXCAP}=\mathrm{T} \mathrm{r}[\mathrm{w}(1-\mathrm{L})-\mathrm{C} 1]
$$




\section{$\mathrm{TAXCAP}=\mathrm{T} \mathrm{rw} / 3$}

The present value of this tax as of the first period is

$$
\mathrm{TACAP} /(1+\mathrm{r})=\mathrm{T} \mathrm{r} \mathrm{w} / 3(1+\mathrm{r}) \text {. }
$$

We are now in a position to calibrate the two tax rates and compare the utility levels that result from the two taxes that produce the same present value of revenue as of the first period.

For this purpose, we take as the standard the labor tax revenue produced by tax rate $t$ and set $\mathrm{T}$ so that $\mathrm{TAXCAP} /(1+\mathrm{r})=\mathrm{TAXL}$. This implies

$$
\mathrm{Trw} / 3(1+\mathrm{r})=2 \mathrm{tw} / 3
$$

or

$$
\mathrm{T}=2 \mathrm{t}(1+\mathrm{r}) / \mathrm{r}
$$

The utility expression derived above:

$$
\mathrm{u}=-3 \ln 3+2 \ln [\mathrm{w}(1-\mathrm{t})]+\ln [1+(1-\mathrm{T}) \mathrm{r}]
$$

implies that with a pure labor income tax (i.e., if $\mathrm{T}=0$ ) the utility level is 


$$
\mathrm{uLAB}=-3 \ln 3+2 \ln w+2 \ln (1-\mathrm{t})+\ln [1+\mathrm{r}]
$$

With no labor income tax but a capital tax that produces the same present value of revenue (i.e., with $\mathrm{T}=2 \mathrm{t}(1+\mathrm{r}) / \mathrm{r}$ ), the utility level is:

$$
\mathrm{uCAP}=-3 \ln 3+2 \ln \mathrm{w}+\ln (1+\mathrm{r})+\ln (1-2 \mathrm{t}) .
$$

The utility level with the pure labor income tax exceeds the utility level with the pure capital income tax if

$$
\text { uLAB > u CAP, }
$$

that is if

$$
\begin{aligned}
& 2 \ln (1-t)>\ln (1-2 t) \text { or, } \\
& \ln (1-t)^{2}>\ln (1-2 t) \text { or } \\
& (1-t)^{2}>(1-2 t)
\end{aligned}
$$

This is true for any $t>0$, showing that for this loglinear utility case the labor tax produces higher utility than a capital tax with equal present value of revenue. 